\title{
Paleogene to Neogene alkaline lavas as a probe of the lithosphere- asthenosphere boundary (LAB) beneath western Canada
}

\author{
D. CANIL ${ }^{1}$, R.D.HYNDMAN ${ }^{2}$, D. FODE ${ }^{3}$ \\ ${ }^{1}$ University of Victoria, Victoria, Canada V8P 5C2 \\ ${ }^{2}$ Pacific Geoscience Centre, Geological Survey of Canada, \\ Canada V8L 4B2 \\ ${ }^{3}$ University of Victoria, Victoria, Canada V8P 5C2
}

The origin and evolution of high heat flow and a thin, hot lithosphere in the North American Cordillera in Canada is debated in geophysically-based models to have formed as either (a) ancient thinned lithosphere or (b) complete wholesale replacement followed by thickening and cooling in the past 5 - 25 Myr. We address this problem using published alkali olivine basalt and basanite lavas $(n=128)$ hosting mantle xenoliths and erupted in the period $28 \mathrm{Ma}$ to $8 \mathrm{ka}$ over most of the region. We invert the bulk composition of the lavas for their P-T of origin using methods described in [1]. Using only mantle xenolith-bearing magmas confirms the lavas are least modified and most likely derived below the LAB. A range of possible $\mathrm{H}_{2} \mathrm{O}, \mathrm{Fe}^{3+} /$ total $\mathrm{Fe}$ and mantle olivine compositions $\left(\mathrm{Fo}_{88-90}\right)$ result in uncertainties of \pm 10 $\mathrm{km}$ and $\mathrm{T}$ of $\pm 5 \%$. Assuming a source mantle with $100 \mathrm{ppm}$ $\mathrm{H}_{2} \mathrm{O}$, the depths of origin for the lava suites varies from $120-$ $55 \mathrm{~km}$ with no obvious spatial variation. The oldest xenolithbearing lavas have the shallowest depth of origin but host the hottest mantle xenolith suite. Extant limited age dating of lavas shows a possible increase in potential temperature (Tp) of $\sim 100 \mathrm{C}$ or increasing $\mathrm{H}_{2} \mathrm{O}$ in the mantle source from 25 Ma to Holocene. The P-T of origin of the lavas is consistent with seismic receiver functions in the western USA that show a $\mathrm{LAB}$ at $65 \pm 10 \mathrm{~km}$ underlain by slow wave speeds (attributed to partial melt) extending to $\sim 150 \mathrm{~km}$. The $\mathrm{LAB}$ is interpreted as the intersection of a $<50$ ppm $\mathrm{H}_{2} \mathrm{O}$ mantle solidus with the Cordilleran geotherm and asthenosphere adiabat - all alkali basalts and basanites can be derived below this from wetter mantle with $>100 \mathrm{ppm}_{2} \mathrm{O}$.

[1] Plank\&Forsyth, 2016, G-cubed 